\title{
Induction of Oxidative Stress by Sunflower Phytotoxins in Germinating Mustard Seeds
}

\author{
Krystyna Oracz • Christophe Bailly • \\ Agnieszka Gniazdowska • Daniel Côme • \\ Francoise Corbineau $\cdot$ Renata Bogatek
}

Received: 18 July 2006 / Revised: 15 October 2006 / Accepted: 2 November 2006 /

Published online: 10 January 2007

(C) Springer Science + Business Media, LLC 2007

\begin{abstract}
The aim of this study was to investigate the phytotoxic effect of sunflower on physiological and biochemical processes during germination of mustard seeds (Sinapis alba L. cv. Nakielska). To exclude the involvement of osmotic stress in seed reaction to phytotoxic compounds, we compared the effect of $10 \%(\mathrm{w} / \mathrm{v})$ water extract from sunflower (Helianthus annuus L. cv. Ogrodowy) leaves and 28.4\% (w/v) polyethylene glycol (PEG) 8000 solution characterized by an equal $\Psi=-1 \mathrm{MPa}$. We evaluated (1) the amount of hydrogen peroxide $\left(\mathrm{H}_{2} \mathrm{O}_{2}\right)$; (2) activities of antioxidant enzymes: superoxide dismutase, catalase, and glutathione reductase; (3) membrane permeability; and (4) level of malondialdehyde (MDA). Both, sunflower compounds and PEG solutions inhibited mustard seed germination, but only phytotoxins caused an increase in the cell membrane permeability, MDA level, $\mathrm{H}_{2} \mathrm{O}_{2}$ concentration, and alterations in activities of antioxidant enzymes. Our results demonstrate that despite the activation of the antioxidant system by sunflower phytotoxins, reactive oxygen species accumulation caused cellular damage, which resulted in the decrease of germinability and gradual loss of seed vigor. It seems that the negative effect of sunflower on germination of mustard seeds is mostly because of its toxicity and not to its contribution to osmotic potential.
\end{abstract}

Keywords Antioxidant enzymes · Germination · Mustard · Osmotic stress · Oxidative stress $\cdot$ Phytotoxicity $\cdot$ Sunflower

K. Oracz $\cdot$ A. Gniazdowska $\cdot$ R. Bogatek $(\square)$

Department of Plant Physiology, Warsaw Agricultural University,

Nowoursynowska 159, 02-776 Warsaw, Poland

e-mail: renata_bogatek@sggw.pl

C. Bailly $\cdot$ D. Côme $\cdot$ F. Corbineau

Physiologie Végétale Appliquée, Université Pierre et Marie Curie-Paris 6,

Boite Courrier 152, 4 place Jussieu, 75252 Paris Cédex 05, France 


\section{Introduction}

Allelopathic interactions refer to both natural and agroecosystems. Most effects reported have been identified as being caused by inhibitors of physiological and biochemical processes in plants from chemicals released from living plants into the environment through root exudation, leaching, and volatilization, and passively through decomposition of plant residues. In recent years, a wide selection of plants has been studied for phytotoxic potential. Among them, Helianthus annuus L. actively influences the growth of surrounding plants (Irons and Burnside, 1982; Shon and Einhellig, 1982; Leather, 1983; Azania et al., 2003). Phytotoxicity of sunflower residues against Sorghum vulgare, Zea mays, Pennisetum americanum, and Cyamopsis tetragonoloba has been reported by Batish et al. (2002). Foliar extracts of sunflower contain chlorogenic and isochlorogenic acids, naphthol derivatives, and scopolin (Wilson and Rice, 1968). In addition, more than other 50 compounds from the active fraction of sunflower extracts have been isolated by Macias et al. (1993, 1996, 1997, 1999, 2000, 2002). Those allelochemicals are mainly terpenoids. Sesquiterpenes are the most abundant, and two new skeletal types, heliannuols and heliespirones, are known.

Like other stress factors, allelochemicals have several molecular targets, and some of their physiological processes or modes of action have been reviewed (Peng et al., 2004; Weir et al., 2004; Gniazdowska and Bogatek, 2005). They include disruption of membrane permeability (Galindo et al., 1999), ion uptake (Lehman and Blum, 1999), inhibition of electron transport in both photosyntetic and the respiratory chain (Peñuelas et al., 1996; Abrahim et al., 2000; Czarnota et al., 2001), alterations of enzyme activities (Cruz-Ortega et al., 1990; Politycka, 1998), and inhibition of cell division (Cruz-Ortega et al., 1988; Anaya and Pelayo-Benavides, 1997). It has also been postulated that allelopathy stress might lead to an imbalance between antioxidant defenses and the amount of reactive oxygen species (ROS), resulting in oxidative stress (Cruz-Ortega et al., 2002; Bais et al., 2003; Romero-Romero et al., 2005).

Although the role of the antioxidant system in plants in response to environmental stresses has received attention (Bowler et al., 1992; Scebba et al., 1998; Yu et al., 2003; Foyer and Noctor, 2005), our understanding about its putative involvement in response to phytotoxic agents is so far not well documented. The scavenging of the superoxide radical $\left(\mathrm{O}_{2}^{-}\right)$is achieved through an upstream enzyme, superoxide dismutase (SOD), which catalyses the dismutation of $\left(\mathrm{O}_{2}^{--}\right)$to hydrogen peroxide $\left(\mathrm{H}_{2} \mathrm{O}_{2}\right)$ and plays a role in protecting cells against the toxic effects of those radicals produced in different cellular compartments (del Rio et al., 2002). Furthermore, the intracellular level of $\mathrm{H}_{2} \mathrm{O}_{2}$ is regulated by a wide range of enzymes, the most important being catalase (CAT) (Blokhina et al., 2003). Synthesis of SOD and CAT as an adaptive response to oxidative stress has been reviewed (Mittler, 2002). In addition, effective resistance to prolonged stress would necessitate an augmented capacity for ascorbate regeneration, a process at least partly dependent on the tripeptide thiol (glutathione) in higher plants (Foyer et al., 1995). An important role in glutathione oxidation to glutathione disulfate is played by the latter enzyme in the ascorbate-glutathione cycle, glutathione reductase (GR). Transgenic plants, which have threefold higher GR activity than the control, have also increased tolerance to oxidative stress induced by paraquat (Inze and Montagu, 1995).

The phytotoxicity of sunflower extracts makes them good candidates as a source of a natural herbicide against weed species (Azania et al., 2003 and references therein). In this study, we studied the effect of an aqueous extract from sunflower leaves (H. annuus L. cv. Ogrodowy) on mustard (Sinapis alba L. cv. Nakielska) seed germination, a common dicotyledonous weed species. Extract from sunflower leaves has a low water potential; 
therefore, we compared the effect of sunflower water extract and polyethylene glycol (PEG) solution (characterized by an equal $\Psi=-1 \mathrm{MPa}$ ) on mustard seed germination.

In view of the increasing evidence on the role of ROS and the contribution of some antioxidant enzymes (CAT, SOD, and GR) to various physiological processes during stress conditions, it was of a particular interest to investigate whether $\mathrm{H}_{2} \mathrm{O}_{2}$ and related oxidative damage i.e. lipid peroxidation and membrane injuries, might play a role in seed responses to sunflower phytotoxic compounds.

\section{Methods and Materials}

Preparation of Sunflower Extract Leaves from field grown sunflower (H. annuus L. cv. Ogrodowy) were harvested at the beginning of the flowering stage. Tissue (leaves) was airdried, and ground to obtain a fine powder. Leaf powder (10 g dry weight [DW]) was extracted for $24 \mathrm{hr}$ in $100 \mathrm{ml}$ of distilled water at $20^{\circ} \mathrm{C}$. The obtained $10 \%(\mathrm{w} / \mathrm{v})$ extract was filtered through filter paper and used as a source of phytotoxins (Bogatek et al., 2006; Kupidłowska et al., 2006).

Plant Material and Germination Tests Germination assays of mustard seeds (S. alba L. cv. Nakielska) were performed by placing seeds (four replicates of 100 seeds each) in 9-cm petri dishes (25 seeds per dish) containing filter paper moistened with distilled water (control), $28.4 \%(\mathrm{w} / \mathrm{v})$ PEG (-1 MPa) solution or $10 \%(\mathrm{w} / \mathrm{v})$ sunflower extract $(-1 \mathrm{MPa})$ at $20^{\circ} \mathrm{C}$ in darkness. Seeds were considered to have germinated when the radicle had pierced the envelope. Dry matter of mustard seeds was determined by oven drying at $105^{\circ} \mathrm{C}$ for $48 \mathrm{hr}$.

Viability Seed viability was estimated with a tetrazolium test. Seeds were cut longitudinally and incubated in $1 \%$ solution of 2,3,5-triphenyltetrazolium chloride for $2 \mathrm{hr}$ at $20^{\circ} \mathrm{C}$ in darkness (Moore, 1973). Seeds in which the embryo exhibited no carmine staining were scored as nonviable.

Biochemical measurements were carried out on mustard seeds after $18 \mathrm{hr}$ and 2, 4, 6, and $8 \mathrm{~d}$ of treatment with sunflower extract. For the control and seeds germinated in the presence of $28.4 \%$ (w/v) PEG ( $-1 \mathrm{MPa}$ ), measurements were carried out only after $18 \mathrm{hr}$ of germination because longer durations of imbibition allowed radicle protrusion (seeds in all combinations were at the same physiological stage).

$\mathrm{H}_{2} \mathrm{O}_{2}$ Concentration Hydrogen peroxide contents of seeds were determined according to the method described by O'Kane et al. (1996). Mustard seeds (0.5 g, fresh weight [FW]) were ground with a mortar and pestle in liquid nitrogen. Samples were homogenized with $10 \mathrm{ml}$ of perchloric acid $(0.2 \mathrm{M})$. After $15 \mathrm{~min}$ of centrifugation at $11,000 \times \mathrm{g}$ at $4^{\circ} \mathrm{C}$, the resulting supernatant was neutralized to $\mathrm{pH} 7.5$ with $\mathrm{KOH}(4 \mathrm{M})$, and then centrifuged at 5,000×g for $3 \mathrm{~min}$ at the same temperature to remove insoluble potassium perchlorate. The obtained supernatant was used for spectrophotometric determination of $\mathrm{H}_{2} \mathrm{O}_{2}$. The reaction mixture contained $50 \mu \mathrm{l}$ of the collected supernatant, $12.5 \mathrm{mM}$ of dimethylaminobenzoic acid, $1.25 \mathrm{mM}$ of 3-methyl-2-benzothiazolidone hydrazone, and $20 \mu \mathrm{l}(0.25 \mathrm{U})$ of horseradish peroxidase for a total volume of $1.5 \mathrm{ml}$. The reaction started with the addition of peroxidase. Increase in absorbance at $590 \mathrm{~nm}$ was monitored after $5 \mathrm{~min}$ at $25^{\circ} \mathrm{C}$ and compared with the absorbance obtained with known amounts of $\mathrm{H}_{2} \mathrm{O}_{2}$, detected for 5 min at $590 \mathrm{~nm}$. Results are expressed as micromoles per gram of DW and correspond to the means of the values $\pm \mathrm{SD}$ obtained with three replicates from three independent experiments. 
Electrolyte Leakage Germinated seeds (on water, PEG solution, or extract from sunflower leaves) were rinsed with distilled water, and solute leakage was determined. Twenty seeds were placed in $15 \mathrm{ml}$ of distilled water at $20^{\circ} \mathrm{C}$ in darkness. Conductivity in the medium was measured with a conductivity meter after $2 \mathrm{hr}$ of incubation period. Results are expressed as percent of total leakage from seeds boiled for 20 min in water and represent the means $\pm \mathrm{SD}$ of the values obtained with three measurements carried out on five replicates.

MDA Content Lipid peroxidation was estimated by measuring spectrophotometrically malondialdehyde (MDA) contents of seeds. The tissue (five seeds) was ground in $5 \mathrm{ml}$ distilled water and homogenized with an equal volume of $0.5 \%(\mathrm{w} / \mathrm{v}) 2$-thiobarbituric acid in $20 \%(\mathrm{w} / \mathrm{v})$ trichloroacetic acid. The homogenate was incubated for $30 \mathrm{~min}$ at $95^{\circ} \mathrm{C}$ in a water bath and then cooled quickly on ice and centrifuged at $16,000 \times g$ for $30 \mathrm{~min}$. The supernatant was used for MDA determination according to Heath and Parker (1968) as described by Bailly et al. (1996). MDA equivalent was calculated from the difference in absorbance at 532 and $600 \mathrm{~nm}$ using an extinction coefficient of $155 \mathrm{mM}^{-1} \mathrm{~cm}^{-1}$. Results are expressed as nanomoles per gram of DW and represent the mean of 3 replicates \pm SD.

SOD, CAT, and GR Extraction Enzyme activities were determined from the extract prepared according to the method of Bailly et al. (1996). All steps of the extraction were carried out at $4^{\circ} \mathrm{C}$. Seeds $(1 \mathrm{~g} \mathrm{FW})$ were homogenized in a cold mortar in $10 \mathrm{ml}$ of $0.1 \mathrm{M}$ potassium phosphate buffer ( $\mathrm{pH} 7.8$ ) containing $2 \mathrm{mM} \alpha$-dithiothreitol, $0.1 \mathrm{mM}$ EDTA, $1.25 \mathrm{mM}$ PEG 4000, and $0.2 \mathrm{~g}$ polyvinylpyrrolidone and mixed for $15 \mathrm{~min}$. The homogenate was centrifuged at $11,000 \times \mathrm{g}$ for $15 \mathrm{~min}$, and the supernatant was filtered through Miracloth, desalted on a PD 10 column (Amersham Biosciences). The obtained extract was immediately used for determination of enzyme activities.

Total SOD (EC 1.15.1.1) Activity of SOD was determined by inhibition of $p$-nitroblue tetrazolium chloride (NBT) photoreduction (Giannopolitis and Ries, 1977). The assay was conducted at $25^{\circ} \mathrm{C}$ in a total volume of $3 \mathrm{ml}$ of $0.1 \mathrm{M}$ potassium phosphate buffer $(\mathrm{pH} \mathrm{7.8)}$ containing $1.3 \mu \mathrm{M}$ riboflavine, $13 \mathrm{mM}$ methionine, $63 \mu \mathrm{M}$ NBT, and $50 \mu \mathrm{l}$ of enzymatic extract, as described by Bailly et al. (1996). Absorbance was monitored at $560 \mathrm{~nm}$ after 15 min of illumination, using a spectrophotometer Pharma Spec UV-1700 (Shimadzu, Japan). One unit of SOD is defined as the amount of enzyme that inhibits NBT photoreduction to blue formazan by $50 \%$, monitored at $560 \mathrm{~nm}$. Superoxide dismutase activity of the extracts was expressed as units of SOD per milligram of protein.

CAT (EC 1.11.1.6) Catalase activity was determined according to Clairbone (1985) with some modifications (Bailly et al., 1996). The assay was carried out in a total volume of $3 \mathrm{ml}$ of $50 \mathrm{mM}$ potassium phosphate buffer ( $\mathrm{pH} 7.0$ ) containing $37.5 \mathrm{mM}$ of $\mathrm{H}_{2} \mathrm{O}_{2}$ and 200 $\mu \mathrm{l}$ of enzyme extract. The decrease in absorbance at $240 \mathrm{~nm}$ because of degradation of $\mathrm{H}_{2} \mathrm{O}_{2} \quad\left(\varepsilon=39.4 \mathrm{mmol}^{-1} \mathrm{~cm}^{-1}\right)$ was monitored every $3 \mathrm{sec}$ for $2 \mathrm{~min}$, using a spectrophotometer, Pharma Spec UV-1700 (Shimadzu). Catalase activity was expressed as nanomoles of $\mathrm{H}_{2} \mathrm{O}_{2}$ decomposed per milligram of protein per minute.

GR (EC 1.6.4.2) Glutathione reductase activity was determined in $800 \mu$ of $0.1 \mathrm{M}$ potassium phosphate buffer $(\mathrm{pH} 7.8)$ containing $0.5 \mathrm{mM} \beta$-nicotinamide adenine dinucleotide 2'-phosphate, reduced form (2'-NADPH); $10 \mathrm{mM}$ glutathione, oxidized form; $3 \mathrm{mM} \mathrm{MgCl}_{2}$; and $50 \mu \mathrm{l}$ enzymatic extract (Bailly et al., 1996). The decline in absorbance 
because of NADPH oxidation was recorded at $340 \mathrm{~nm}$ every $30 \mathrm{sec}$ for 6-8 min using a spectrophotometer, Pharma Spec UV-1700 (Shimadzu). Glutathione reductase activity was expressed as nanomoles of NADPH oxidized per milligram of protein per minute. All results correspond to the means $\pm \mathrm{SD}$ of the values obtained with three measurements carried out in three independent experiments.

Protein Determination Protein content in the enzymatic extracts was determined by using a Bradford reagent (Bradford 1976). Bovine serum albumin (Sigma) was used as a calibration standard.

Measurement of Water Potential WP4 Dewpoint Potential Meter (Decagon Devices, Inc., Pullman, WA, USA) was used to measure water potential $(\Psi)$ of $10 \%(\mathrm{w} / \mathrm{v})$ sunflower extract and $28.4 \%$ (w/v) PEG 8000 solution. Samples of both solutions were monitored at $20^{\circ} \mathrm{C}$. Results correspond to the means $\pm \mathrm{SD}$ of the values obtained with three measurements carried out for three of each independent prepared solutions.

Statistical Analysis The values of germinability and viability were represented as means \pm $\mathrm{SE}$ from four independent experiments, whereas the remaining data were means $\pm \mathrm{SE}$ from three replicates from three independent experiments. Significant differences between values of $\mathrm{H}_{2} \mathrm{O}_{2}$ concentration, membrane injury, MDA concentration, and enzyme activities, which were measured in dry mustard seeds and germinating mustard seeds in the presence of water, PEG solution, and sunflower extract, were determined at $P \leq 0.05$ according to Duncan's multiple range test.

\section{Results}

Germination and Viability Almost all (95\%) mustard seeds germinated on water (control) within $3 \mathrm{~d}$ at $20^{\circ} \mathrm{C}$ and produced typical etiolated seedlings $7-8 \mathrm{~cm}$ long after $8 \mathrm{~d}$ (Fig. 1).

Fig. 1 Mustard seed germination in the presence of water, PEG, and sunflower extract. Data are means \pm SD from four independent experiments

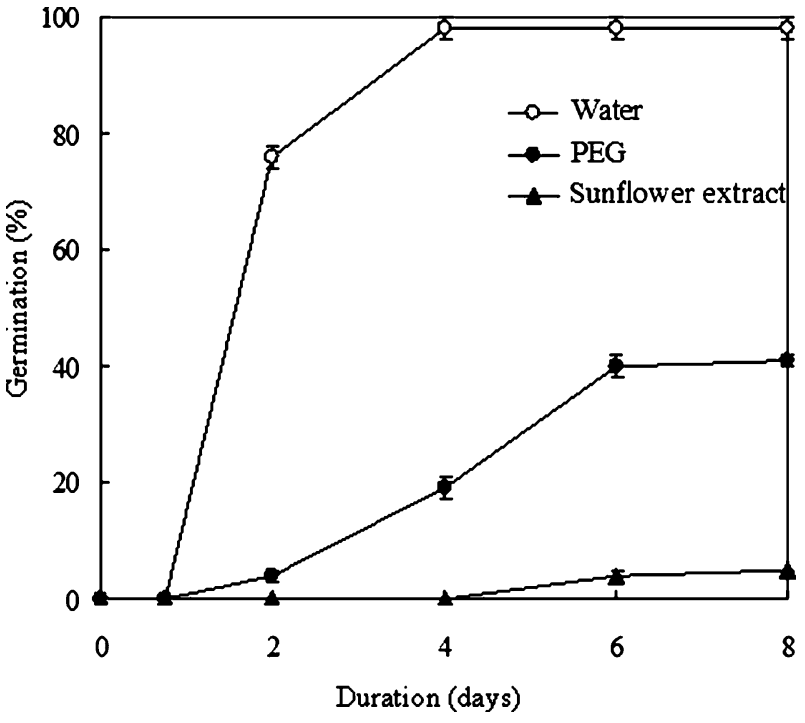


The water potential of $28.4 \%(\mathrm{w} / \mathrm{v})$ PEG equaled that of the $10 \%(\mathrm{w} / \mathrm{v})$ sunflower extract and reached $-1 \mathrm{MPa}$. Germination on $28.4 \%$ PEG solution $(\Psi=-1 \mathrm{MPa})$ was inhibited by almost $50 \%$; after $8 \mathrm{~d}$ of incubation on PEG solution, only $48 \%$ of seeds germinated and produced etiolated seedlings 5-6 cm long (Fig. 1). The water extract from sunflower leaves $(10 \% \mathrm{w} / \mathrm{v},-1 \mathrm{MPa})$ strongly affected germination of mustard seeds. After $8 \mathrm{~d}$ of exposure to phytotoxic compounds, only $5 \%$ of seeds germinated (Fig. 1) and failed to develop into normal seedlings (data not shown). For the duration of the test, in the presence of sunflower toxins, no radicles pierced the seed envelope, nor was seedling growth noticed. Those seeds, throughout the course of the experiment, remained at the stage comparable to seeds immersed in water after $18 \mathrm{hr}$. Therefore, seeds after $18 \mathrm{hr}$ $(0.75 \mathrm{~d})$ of imbibition in water were regarded as a potential control for comparative purposes, owing to their similar morphological and physiological growth stage to treated seeds.

Results of the tetrazolium test (Fig. 2) showed that almost all seeds incubated on water were viable. During the time of germination, control seed viability was not changed and we obtained $95 \%$ viable seeds (Fig. 2). Similarly, the viability of seeds treated by PEG reached $92 \%$ and was constant till the end of the experiment (Fig. 2). During the first $4 \mathrm{~d}$ of germination in the presence of sunflower extract, $84 \%$ of the seeds remained viable (Fig. 2), although they did not germinate (Fig. 1). A longer treatment with sunflower extract was lethal, and the tetrazolium test showed that seed viability decreased progressively to $65 \%$ at the eight day and to $2 \%$ of viable seeds after $14 \mathrm{~d}$ (Fig. 2).

$\mathrm{H}_{2} \mathrm{O}_{2}$ Concentration Hydrogen peroxide concentration (Fig. 3) in dry seeds and seeds imbibed with water was 0.11 and $1.33 \mu \mathrm{mol} \mathrm{g}{ }^{-1} \mathrm{DW}$, respectively. Similar values of $\mathrm{H}_{2} \mathrm{O}_{2}$ level $\left(1.05 \mu \mathrm{mol} \mathrm{g}{ }^{-1} \mathrm{DW}\right)$ were observed in seeds germinated on PEG solution (Fig. 3). Sunflower phytotoxic compounds increased $\mathrm{H}_{2} \mathrm{O}_{2}$ concentration in mustard seeds. After $18 \mathrm{hr}$, it was more than three times as high $\left(3.9 \mu \mathrm{mol} \mathrm{g}{ }^{-1} \mathrm{DW}\right)$ as in the control and seeds imbibed on PEG, and increased progressively, reaching $5.78 \mu \mathrm{mol} \mathrm{g}^{-1} \mathrm{DW}$ at the fourth day and $7.12 \mu \mathrm{mol} \mathrm{g}^{-1} \mathrm{DW}$ at the eight day (Fig. 3).

Fig. 2 Viability of mustard seeds in the presence of water, PEG, and sunflower extract. Data are means \pm SD from four independent experiments

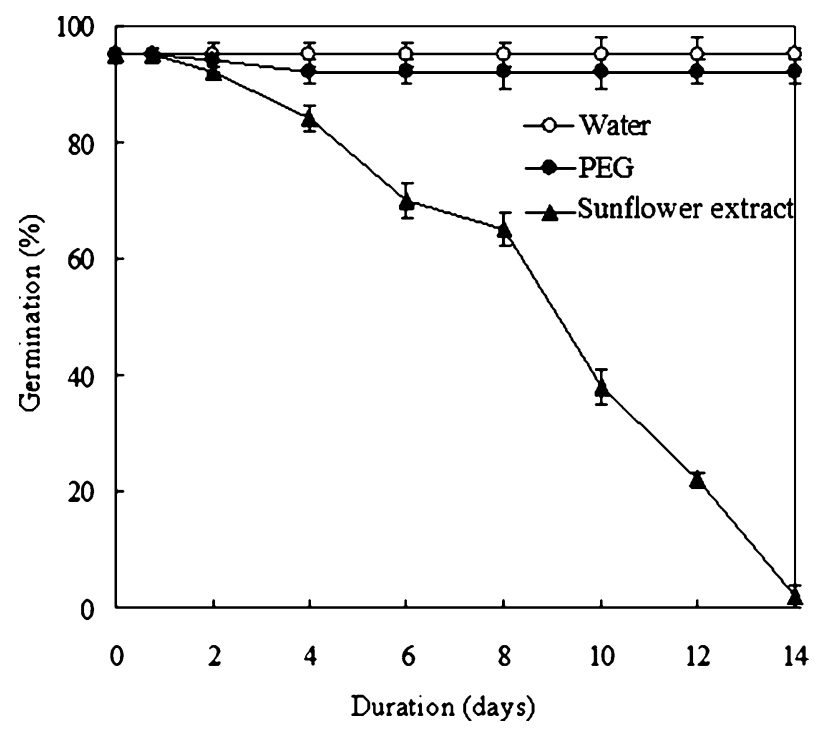


Fig. $3 \mathrm{H}_{2} \mathrm{O}_{2}$ concentration in dry mustard seeds and germinating mustard seeds in the presence of water, PEG, and sunflower extract. Data are means \pm SD from three replicates from three independent experiments. Significant differences $a, b$, and $c$ at the $5 \%$ level between mustard seeds germinated in the presence of water, PEG solution, and sunflower extract $(P \leq 0.05$, according to Duncan's multiple range test)

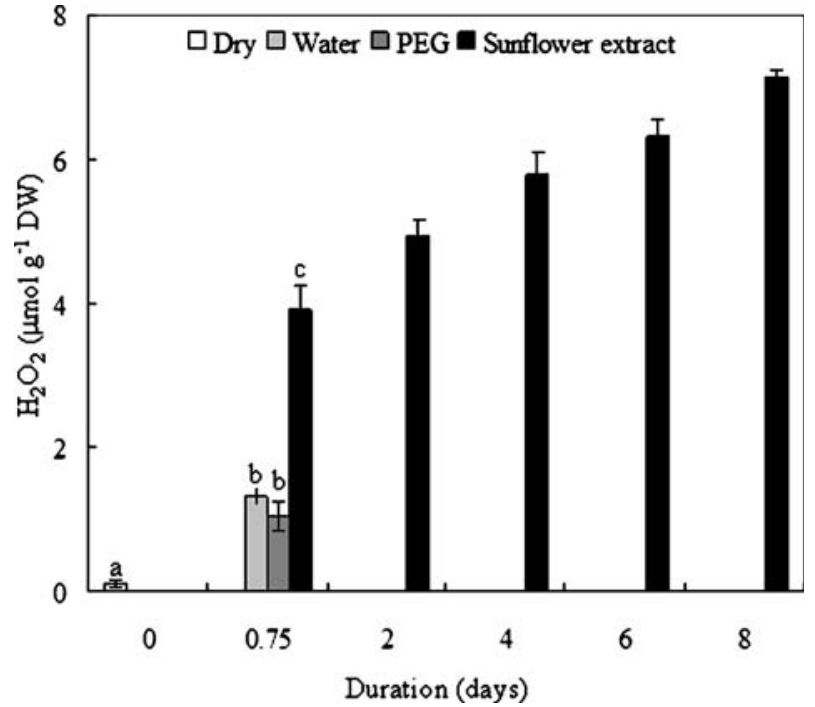

Electrolyte Leakage Ion leakage (Fig. 4) from dry mustard seeds or after $18 \mathrm{hr}$ of imbibition on water and PEG solution was low $(0.5,4$, and $5 \%$ of total leakage, respectively). Treatment of seeds by sunflower extract led to a rapid and marked increase in electrolyte leakage. It represented $19.5 \%$ of total leachable electrolytes after $18 \mathrm{hr}$ and increased continuously during the experiment. After $8 \mathrm{~d}$ of incubation of mustard seed in the presence of sunflower compounds, electrolyte leakage reached $33 \%$ of total electrolyte leakage (Fig. 4).

MDA Content The level of MDA (Fig. 5) in dry seeds was $1.3 \mathrm{nmol} \mathrm{g}^{-1}$ DW. After $18 \mathrm{hr}$ of imbibition on water, PEG solution, or sunflower compounds, the MDA content of mustard

Fig. 4 Membrane injury in dry mustard seeds and germinating mustard seeds in the presence of water, PEG, and sunflower extract. Data are means \pm SD from three replicates from three independent experiments. Significant differences $a, b$, and $c$ at the $5 \%$ level between mustard seeds germinated in the presence of water, PEG solution, and sunflower extract $(P \leq 0.05$, according to Duncan's multiple range test)

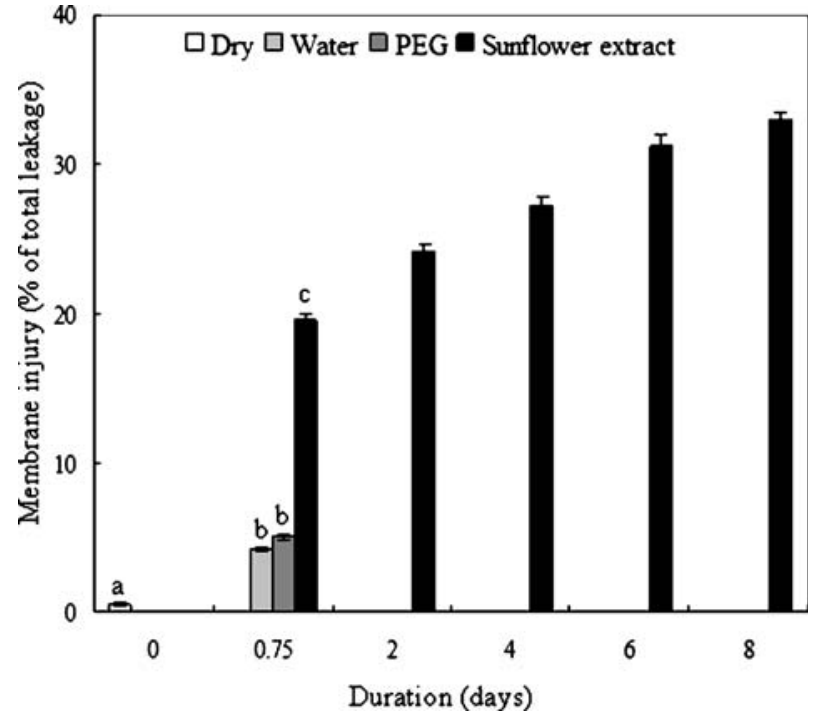


Fig. 5 Malondialdehyde (MDA) concentration in dry mustard seeds and germinating mustard seeds in the presence of water, PEG, and sunflower extract. Data are means \pm SD from three replicates from three independent experiments. Significant differences $a$ and $b$ at the 5\% level between mustard seeds germinated in the presence of water, PEG solution, and sunflower extract $(P \leq 0.05$, according to Duncan's multiple range test)

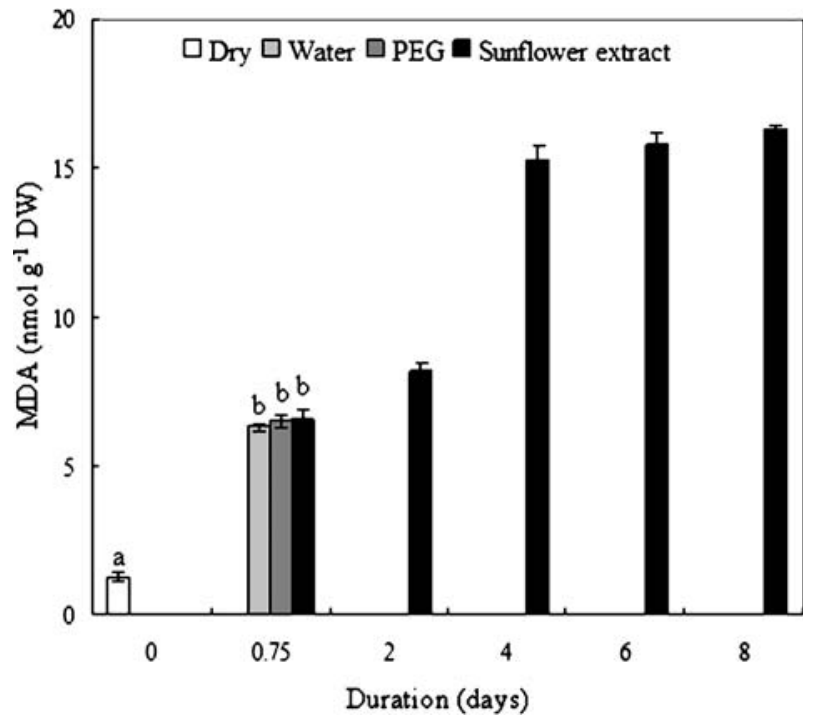

seeds increased to ca. $6.3,6.5$, and $6.6 \mathrm{nmol} \mathrm{g}^{-1} \mathrm{DW}$, respectively. Prolonged phytotoxic stress was associated with an increase of MDA concentration until the fourth day, and it remained at a constant value, close to $15.3 \mathrm{nmol} \mathrm{g}^{-1} \mathrm{DW}$ till the end of the experiment.

Activities of Antioxidant Enzymes Superoxide dismutase activity (Table 1) in dry mustard seeds was $4.61 \mathrm{U} \mathrm{mg}^{-1}$ protein. Eighteen hours of imbibition on water, PEG solution, or sunflower extract resulted in an increase of SOD activity to values 7.28, 6.60, and 7.32 U $\mathrm{mg}^{-1}$ protein, respectively. The prolonged treatment by sunflower extract increased SOD activity, and after $8 \mathrm{~d}$ of germination it was almost doubled, compared to seeds in the imbibed in water, and reached a value $12.11 \mathrm{U} \mathrm{mg}^{-1}$ protein.

Table 1 Antioxidant enzyme activities in dry mustard seeds and germinating mustard seeds in the presence of water, PEG solution, and sunflower extract

\begin{tabular}{|c|c|c|c|c|}
\hline \multirow[b]{2}{*}{ Combination } & \multicolumn{4}{|c|}{ Enzyme Activity } \\
\hline & Days & $\begin{array}{l}\text { SOD (units } \mathrm{mg}^{-1} \\
\text { protein) }\end{array}$ & $\begin{array}{l}\mathrm{CAT}\left(\mathrm{nmol} \mathrm{H} \mathrm{H}_{2} \mathrm{O}_{2} \mathrm{mg}^{-1}\right. \\
\left.\text { protein } \min ^{-1}\right)\end{array}$ & $\begin{array}{l}\text { GR (nmol NAPDH } \mathrm{mg}^{-1} \\
\left.\text { protein } \min ^{-1}\right)\end{array}$ \\
\hline Dry & 0 & $4.61 \pm 0.14^{\mathrm{a}}$ & $0.01 \pm 0.005$ & ND \\
\hline Water & 0.75 & $7.28 \pm 0.22^{\mathrm{a}}$ & $0.95 \pm 0.03$ & $2.11 \pm 0.06^{\mathrm{a}}$ \\
\hline PEG & 0.75 & $6.60 \pm 0.20^{\mathrm{a}}$ & $1.34 \pm 0.04$ & $1.84 \pm 0.05^{\mathrm{a}}$ \\
\hline \multirow[t]{5}{*}{ Sunflower extract } & 0.75 & $7.32 \pm 0.22^{\mathrm{a}}$ & $1.17 \pm 0.03$ & $0.31 \pm 0.01^{\mathrm{a}}$ \\
\hline & 2 & $9.33 \pm 0.28$ & $1.84 \pm 0.05$ & $1.37 \pm 0.04$ \\
\hline & 4 & $11.03 \pm 0.33$ & $4.63 \pm 0.09$ & $1.52 \pm 0.05$ \\
\hline & 6 & $11.33 \pm 0.34$ & $6.03 \pm 0.12$ & $1.64 \pm 0.05$ \\
\hline & 8 & $12.11 \pm 0.36$ & $9.17 \pm 0.27$ & $2.06 \pm 0.06$ \\
\hline
\end{tabular}

Data are means \pm SD from three replicates from three independent experiments.

${ }^{a}$ Significant differences at the 5\% level between mustard seeds germinated in the presence of water, PEG solution, and sunflower extract ( $P \leq 0.05$, according to Duncan's multiple range test).

$\mathrm{ND}=$ not detected 
Catalase activity (Table 1) in dry seeds was $0.01 \mathrm{nmol} \mathrm{H}_{2} \mathrm{O}_{2} \mathrm{mg}^{-1}$ protein $\mathrm{min}^{-1}$. After $18 \mathrm{hr}$ of imbibition, it increased similarly in each three combinations (control, PEG solution, and sunflower extract), reaching values of $0.95,1.34$, and $1.17 \mathrm{nmol} \mathrm{H}_{2} \mathrm{O}_{2} \mathrm{mg}^{-1}$ protein $\mathrm{min}^{-1}$, respectively. The prolonged seed incubation on sunflower extract resulted in a further increase of CAT activity. After $8 \mathrm{~d}$ of exposure to phytotoxins, it achieved $9.17 \mathrm{nmol} \mathrm{H}_{2} \mathrm{O}_{2} \mathrm{mg}^{-1}$ protein $\min ^{-1}$.

Glutathione reductase activity (Table 1) in dry mustard seeds was not detected but during $18 \mathrm{hr}$ of imbibition on water and PEG solution it increased significantly (2.11 and

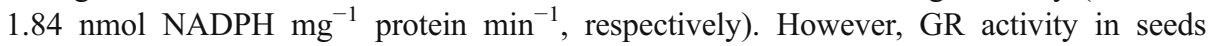
imbibed $18 \mathrm{hr}$ on sunflower extract was eight times lower than that measured in control or seeds treated by PEG solution. Subsequent imbibition of seeds imbibed in the present of sunflower toxins resulted in increase of GR activity. After $8 \mathrm{~d}$ of phytotoxin treatment, it increased to a value similar to that observed in the control and osmotic stressed seeds after $18 \mathrm{hr}$ of incubation, and reached $2.06 \mathrm{nmol} \mathrm{NADPH} \mathrm{mg}{ }^{-1}$ protein $\mathrm{min}^{-1}$.

\section{Discussion}

The most widely used biological assays for the action of phytotoxins are seed germination and seedling growth studies. The delay and reduction of seed germination and/or inhibition of root and shoot growth are usually the first visible symptoms of phytotoxic stress (Dayan et al., 2000). It was previously demonstrated that sunflower produces different allelochemicals that exhibit phytotoxicity against many plant species (Macias et al., 1999, 2002) and, therefore, might be used as an alternative strategy for weed control (Leather, 1983, Azania et al., 2003). Our previous study confirmed that the effect of aqueous sunflower foliar extracts on mustard seed germination is dose-dependent (Bogatek et al., 2006). Germination of mustard seeds is almost fully inhibited by $10 \%$ (w/v) water extract of sunflower leaves (Fig. 1). The osmotic potential of sunflower extract used in our experiment was determined to be close to $-1 \mathrm{MPa}$, and for that reason PEG solution characterized by the same osmotic potential was used to determine whether the inhibition of germination resulted from limited water availability. Imbibition of seeds on PEG solution did not fully inhibit their germination but delayed radicle protrusion and finally allowed $48 \%$ of seeds to germinate (Fig. 1). Thus, the inhibitory effect of sunflower foliar extracts on germination cannot be explained by a limitation in water availability, but rather by a toxic effect of the extract, as shown by the viability test (Fig. 2).

Many identified allelochemicals inhibit or delay seed germination. (-)-Catechin, the allelochemical from root exudates of Centaurea maculosa inhibited germination of Festuca idahoensis and Koelaria micrantha (Bais et al., 2003). Different phenolic compounds (vanillic, $p$-coumaric, and protocatechuic acids) used at concentrations from $10^{-5}$ to $10^{-6} \mathrm{M}$ reduced germination of Pinus laricio seeds (Musculo et al., 2001). Capsaicin isolated from Capsicum spp. at the concentration 10-90 mM suppressed germination of lettuce (Lactica sativa), crabgrass (Digitaria sanguinalis), timothy (Phleum pretense), and ryegrass (Lolium multiflorum) (Kato-Noguchi and Tanaka, 2003-2004). Although allelochemicals act as inhibitors of seed germination, their mode of action often remains unclear. Recently, it was proposed that oxidative stress could play a role in phytotoxic phenomenon (Weir et al., 2004). The exposure of cucumber roots to ferulic and $p$-coumaric acids resulted in increased $\mathrm{H}_{2} \mathrm{O}_{2}$ concentration in the tissue (Politycka, 1996). Bais et al. (2003) showed that 
(-)-catechin elicits a burst of ROS in susceptible plant roots, and the kinetics of ROS induction was similar to the patterns of cell death induced by (-)-catechin. The toxicity of many quinones and phenols can largely be attributed to the formation of semiquinone radicals that donate electrons to molecular oxygen, forming superoxide anions $\left(\mathrm{O}_{2}^{--}\right)$(Weir et al., 2004). Our results show that an increase in $\mathrm{H}_{2} \mathrm{O}_{2}$ content occurs early during mustard seed imbibition in sunflower extract (Fig. 3). We demonstrate that the detrimental effect of sunflower on germination of mustard seeds is not strictly associated with water stress (comparison of PEG and phytotoxins treatment) but rather with the imposition of a precocious oxidative stress.

One of the best known cellular targets of oxidative stress is lipid peroxidation, which is a free-radical chain process leading to the deterioration of polyunsaturated fatty acids (PUFAs). Lipid peroxidation is likely to degrade PUFAs present in membranes, leading to severe damage to membranes or to reserve lipids of oily seeds (Scandalios, 1993; Foyer et al., 1994). One of the indicators of plasma membrane damage is electrolyte leakage measurement. After $8 \mathrm{~d}$ of incubation of mustard seed on sunflower compounds, ion leakage reached $35 \%$ of total leachable electrolytes, thus suggesting damage to plasma membranes (Fig. 4). This observation is in agreement with that obtained with cucumber cotyledons treated with natural sesquiterpenolide, dehydrozaluzanin $\mathrm{C}$, causing a dramatic and rapid plasma membrane leakage (Galindo et al., 1999). In the present paper, symptoms of membrane injuries occurred concomitantly to $\mathrm{H}_{2} \mathrm{O}_{2}$ accumulation (Fig. 3) and preceded an increase in the content of MDA, a compound that reveals the occurrence of measurable processes of lipid peroxidation (Fig. 5). Lipid peroxidation, therefore, seemed to occur when seeds started to die, i.e., after $4 \mathrm{~d}$ of treatment by phytotoxins (Fig. 2), and thus refers to deep damage of the seed lipid component that may concern either membrane or reserve lipids. Storage materials in mustard seeds are mainly proteins (ca. 60\%) and lipids (ca. 40\%), depending on the variety and environmental conditions. Increased lipid peroxidation in the presence of phytotoxins has also been shown in tomato roots (Cruz-Ortega et al., 2002) and in cucumber roots (Politycka, 1996). Damage of the whole membrane system of different plants (rape, cucumber, corn, and sorghum) analyzed at the biochemical and ultrastructural level has been detected in the presence of secalonic acid F, produced by Aspergillus japonicus (Zeng et al., 2001). Allelochemicals can damage cell membranes through direct interaction with a constituent of the membrane, or can result in an impairment of some metabolic processes necessary for the maintenance of membrane function.

With regard to the possible roles of oxidative stress in phytotoxicity, the changes in the main antioxidant enzymes have been investigated during seed imbibition on sunflower leaf extract. During the first $2 \mathrm{~d}$ of sunflower treatment, SOD and CAT activities did not evolve significantly and were similar to those measured in seeds imbibed in water (Table 1). However, GR activity was transiently and dramatically reduced by sunflower foliar extract (Table 1), which may account, at least in part, for the increase of $\mathrm{H}_{2} \mathrm{O}_{2}$ in the treated seeds (Fig. 3). Glutathione reductase is known to play a role in the control of endogenous $\mathrm{H}_{2} \mathrm{O}_{2}$ through its participation in the ascorbate-glutathione cycle and through the formation of reduced glutathione, a compound able to scavenge ROS (Goel et al., 2003). Its impairment would alter the scavenging ability of the cellular ROS and lead to an unbalanced accumulation of $\mathrm{H}_{2} \mathrm{O}_{2}$. Longer treatment of seeds by allelochemicals, i.e., from the fourth to eight day, was associated with a stimulation of CAT and SOD activities and with the recovery of GR activity (Table 1). Indeed, ROS are known to regulate the expression of many genes. One commonly cited possibility concerns the activation of transcription factors by redox status changes (Foyer and Noctor, 2003). Alternatively, gene 
promoter regions may possess antioxidant response elements suspected to play a role in either $\mathrm{H}_{2} \mathrm{O}_{2}$ or antioxidant sensing, as in the case of the maize CAT Cat1 gene (Scandalios et al., 1997). We cannot exclude the possibility that sunflower phytotoxins may influence synthesis of CAT isoforms. Western blot analysis showed that enhancement of CAT activity is associated with synthesis of CAT 5 and CAT 6 isoforms in seeds treated by sunflower extract (Oracz, personal communication). The results provide evidence that the effect of phytotoxins is not direct but occurs through regulation of ROS level in cells of mustard seeds. However, this stimulation of the cell antioxidant system was insufficient to avoid $\mathrm{H}_{2} \mathrm{O}_{2}$ accumulation (Fig. 3) or to prevent lipid peroxidation (Fig. 5) and did not prevent cell death (Fig. 2). Our data are consistent with those of Yu et al. (2003), which showed that exposure of cucumber roots to phytotoxic compounds significantly increased SOD activity. An increased CAT activity in response to allelochemicals has also been demonstrated in germinating cucumber seeds treated by different benzoic acids (Maffei et al., 1999). Romero-Romero et al. (2005) observed increased CAT activity in tomato affected by phytotoxins from Sicyos deppei. However, regarding the complex composition of sunflower leaves extract (Macias et al., 2002) it is not possible to conclude that there is a specific effect of phytotoxic compounds on antioxidant enzymes. Furthermore, it is known that activity and expression of most antioxidant enzymes is stimulated by ROS accumulation (Vranova et al., 2002; de Gara et al., 2003; Apel and Hirt, 2004). The first effect of sunflower phytotoxicity is a dramatic increase in $\mathrm{H}_{2} \mathrm{O}_{2}$ concentration and an inhibition of GR activity. It is thus highly probable that the observed stimulation of antioxidant enzymes does not result from a direct effect of sunflower compounds but is rather a consequence of the oxidative burst that occurs during the first hours of seed imbibition.

The presented data show that although some disturbances in seed metabolism during the germination process are common in both phytotoxic and osmotic stress, the markedly different response is a dramatic increase in the concentration of $\mathrm{H}_{2} \mathrm{O}_{2}$ and changes in GR activity. Therefore, we conclude that despite the similar effect caused by both stresses (inhibition/delay of germination), the mode of their action is different at the biochemical level, as was previously suggested by Romero-Romero et al. (2005).

Our results bring together several lines of evidence, indicating that the deleterious effect of phytotoxins on germination may occur through the imposition of an oxidative stress. The specific effect of sunflower compounds on GR activity explains, in part, the accumulation of $\mathrm{H}_{2} \mathrm{O}_{2}$, but future studies will have to deal with the precise mechanisms of ROS production during this treatment.

Acknowledgements We thank Stewart A. Brown, Professor Emeritus of Trent University, Peterborough, Ontario, Canada for assistance in preparing the English version of the manuscript.

\section{References}

Abrahim, D., Braguini, W. L., Kelmer-Bracht, A. M., and Ishit-Iwamoto, E. L. 2000. Effects of four monoterpenes on germination, primary root growth, and mitochondrial respiration of maize. J. Chem. Ecol. 26:611-624.

Anaya, A. L. and Pelayo-Benavides, H. P. 1997. Allelopathic potential of Mirabilis jalapa L. (Nyctaginaceae): Effects on germination, growth and cell division of some plants. Allelopathy J. 4:57-68.

APEL, K. and HIRT, H. 2004. Reactive oxygen species: Metabolism, oxidative stress and signal transduction. Annu. Rev. Plant Biol. 55:373-399. 
Azania, A. A. P. M., Azania, C. A. M., Alves, P. L. C. A., Palaniraj, R., Kadian, H. S., Sati, S. C., Rawat, L. S., DahiYA, D. S., and Narwal, S. S. 2003. Allelopathic plants. Sunflower (Helianthus annuus L.). Allelopathy J. 11:1-20.

Bailly, C., Benamar, A., Corbineau, F., and Côme, D. 1996. Changes in malondialdehyde content and in superoxide dismutase, catalase and glutathione reductase activities in sunflower seeds as related to deterioration during accelerated aging. Physiol. Plant. 97:104-110.

Bais, H. P., Vepachedu, R., Gilroy, S., Callaway, R. M., and Vivanco, J. M. 2003. Allelopathy and exotic plant invasion: from molecules and genes to species interactions. Science 301:1377-1380.

Batish, D. R., Tung, P., Singh, H. P., and Kohli, R. K. 2002. Phytotoxicity of sunflower residues against some summer season crops. J. Agron. Crop Sci. 188:19-24.

Blokhina, O., Virolainen, E., and Fagersted, K. V. 2003. Antioxidants, oxidative damage and oxygen deprivation stress: a review. Ann. Bot. 91:179-194.

BogateK, R., Gniazdowska, A., ZakrZewska, W., Oracz, K., and Gawroñski, S. W. 2006. Allelopathic effect of sunflower extracts on mustard seed germination and seedling growth. Biol. Plant. 50:156-158.

Bowler, C., Montagu, M. V., and InZe, D. 1992. Superoxide dismutase and stress tolerance. Annu. Rev. Plant Physiol. Plant Mol. Biol. 43:83-116.

BRADFORD, M. M. 1976. A rapid and sensitive method for the quantitation of microgram quantities of protein utilizing the principle of protein-dye binding. Anal. Biochem. 72:248-254.

Clairbone, A. 1985. Catalose activity, pp. 283-284, in R. A. Greenwald (ed.). Handbook of Methods of Oxygen Radical Research. CRC Press, Boca Raton, FL.

Cruz-Ortega, R., ANAYA, A. L., and RAmos, L. 1988. Effects of allelopathic compounds of corn pollen on respiration and cell division of watermelon. J. Chem. Ecol. 14:71-86.

Cruz-Ortega, R., Anaya, A. L., Gavilanes-Ruiz, M., SÁnchez-Nieto, S., and Jimmenez-Estrada, M. 1990. Effect of diacetyl piquerol on the $\mathrm{H}^{+}$-ATPase activity of microsomes from Ipomoea purpurea. J. Chem. Ecol. 16:2253-2261.

Cruz-Ortega, R., Ayala-Cordero, G., and AnayA, L. A. 2002. Allelochemical stress produced by aqueous leachate of Callicarpa acuminata: effects on roots of bean, maize, and tomato. Physiol. Plant. 116:20-27.

Czarnota, M. A., Paul, R. N., Dayan, F. E., Nimbal, C. I., and Weston, L. A. 2001. Mode of action, localization of production, chemical nature and activity of sorgoleone: A potent PSII inhibitor in Sorghum spp. root exudates. Weed Technol. 15:813-825.

Dayan, F. E., Romagni, J. G., and Duke, S. O. 2000. Investigating the mode of action of natural phytotoxins. J. Chem. Ecol. 26:2079-2094.

De Gara, L., De Pinto, M. C., and Tommasi, F. 2003. The antioxidant systems vis-a-vis reactive oxygen species during plant-pathogen interaction. Plant Physiol. Biochem. 41:863-870.

Del Rio, L. A., Corpas, F. J., Sandalio, L. M., Palma, J. M., Gomez, M., and Barroso, J. B. 2002. Reactive oxygen species, antioxidant systems and nitric oxide in peroxisomes. J. Exp. Bot. 53:1255-1272.

Foyer, C. H. and NOCTOR, G. 2003. Redox sensing and signalling, associated with reactive oxygen in chloroplasts, peroxisomes and mitochondria. Physiol. Plant. 119:355-364.

Foyer, C. H. and Noctor, G. 2005. Oxidant and antioxidant signalling in plants: a re-evaluation of the concept of oxidative stress in a physiological context. Plant Cell Environ. 28:1056-1071.

Foyer, C. H., Descourvieres, P., and KunERT, K. J. 1994. Protection against oxygen radicals: an important defence mechanism studied in transgenic plants. Plant Cell Environ. 17:507-523.

Foyer, C. H., Souriau, N., Perret, S., Lelandis, M., Kunert, K. J., Pruvost, C., and Jouanin, L. 1995. Overexpression of glutathione reductase but not glutathione synthetase leads to increase in antioxidant capacity and resistance to photoinhibition in poplar trees. Plant Physiol. 109:1047-1057.

Galindo, J. C. G., Hernandez, A., Dayan, F. E., Tellez, M. R., Macias, F. A., Paul, R. N., and Duke, S. O. 1999. Dehydrozaluzanin C, a natural sesquiterpenolide, causes rapid plasma membrane leakage. Phytochemistry 52:805-813.

Giannopolitis, C. N. and Ries, S. K. 1977. Superoxide dismutases I. Occurrence in higher plants. Plant Physiol. 59:309-314.

GNiazdowsKa, A. and BogateK, R. 2005. Allelopathic interactions between plants. Multi site action of allelochemicals. Acta Physiol. Plant. 27:395-407.

Goel, A., Goel, A. K., and Sheoran, I. S. 2003. Changes in oxidative stress enzymes during artificial ageing in cotton (Gossypium hirsutum L.) seeds. J. Plant Physiol. 160:1093-1100.

HEATH, R. L. and PARKER, L. 1968. Photoperoxidation in isolated chloroplasts. I. Kinetics and stoichiometry of fatty acid peroxidation. Arch. Biochem. Biophys. 125:189-198.

InZE, D. and Montagu, V. 1995. Oxidative stress in plants. Curr. Opin. Biotechnol. 6:153-158.

IRONS, S. and BuRNSIDE, O. C. 1982. Competitive and allelopathic effect of sunflower (Helianthus annuus). Weed Sci. 30:372-377.

Kato-Noguchi, H. and TAnaKa, Y. 2003-2004. Effects of capsaicin on plant growth. Biol. Plant. 47:157-159. 
Kupidłowska, E., Gniazdowska, A., Stęrień, J., Corbineau, F., Vinel, D., Skoczowsk, A., JANECZKO, A., and BOGATEK, R. 2006. Impact of sunflower (Helianthus annuus L.) extracts upon reserve mobilization and energy metabolism in germinating mustard (Sinapis alba L.) seeds. J. Chem. Ecol. DOI 10.1007/s10886-006-9183-z.

LeAther, G. R. 1983. Sunflowers (Helianthus annuus) are allelopathic to weeds. Science 31:37-42.

LEHMAN, M. E. and Blum, U. 1999. Evaluation of ferulic acid uptake as a measurement of allelochemical dose: effective concentration. J. Chem. Ecol. 25:2585-2600.

Macias, F. A., Varela, R. M., Torres, A., and Molinillo, J. M. G. 1993. Potential allelopathic guaianolides from cultivar sunflower leaves, var. SH-222. Phytochemistry 34:669-674.

Macias, F. A., Varela, R. M., Torres, A., and Molinillo, J. M. G. 1996. Potential allelopathic sesquiterpene lactones from sunflower leaves. Phytochemistry 43:1205-1215.

Macias, F. A., Varela, R. M., Torres, A., Oliva, R. M., and Molinillo, J. M. G. 1997. Bioactive norsesquiterpenes from Helianthus annuus with potential allelopathic activity. Phytochemistry 48:631-636.

Macias, F. A., Oliva, R. M., Varela, R. M., Torres, A., and Molinillo, J. M. G. 1999. Allelochemicals from sunflower leaves cv. Peredovick. Phytochemistry 52:613-621.

Macias, F. A., Varela, R. M., Torres, A., and Molinillo, J. M. G. 2000. Potential allelopathic activity of natural plant heliannanes: a proposal of absolute configuration and nomenclature. J. Chem. Ecol. 26:2173-2186.

Macias, F. A., Varela, R. M., Torres, A., Galindo, J. L. G., and Molinillo, J. M. G. 2002. Allelochemicals from sunflowers: chemistry, bioactivity and applications, pp. 73-87, in Inderjit and A. U. Mallik (eds.). Chemical Ecology of Plants: Allelopathy in Aquatic and Terrestrial Ecosystems. Birkhauser Verlag, Basel.

Maffei, M., Bertea, C. M., Garneri, F., and ScAnneri, S. 1999. Effect of benzoic acid hydroxy- and methoxy-ring substituents during cucumber (Cucumis sativus L.) germination. I. Isocitrate lyase and catalase activity. Plant Sci. 141:139-147.

MitTler, R. 2002. Oxidative stress, antioxidants and stress tolerance. Trends Plant Sci. 7:405-409.

MoORE, R. P. 1973. Tetrazolium staining for assessing seed quality, pp. 347-366, in W. Heydecker (ed.). Seed Ecology. Butterworths, London.

Musculo, A., PAnuccio, M. R., and Sidari, M. 2001. The effect of phenols on respiratory enzymes in seed germination. Respiratory enzyme activities during germination of Pinus laricio seeds treated with phenols extracted from different forest soils. Plant Growth Regul. 35:31-35.

O'KAnE, D., Gill, V., Boyd, P., and Burdon, R. 1996. Chilling, oxidative stress and antioxidant responses in Arabidopsis thaliana callus. Planta 198:371-377.

Peng, S. L., Wen, J., and GuO, Q. F. 2004. Mechanism and active variety of allelochemicals. Acta Bot. Sin. 46:757-766.

PEÑUelas, J., RiBAS-CARBO, M., and GILES, L. 1996. Effect of allelochemicals on plant respiration and oxygen isotope fractionation by alternative oxidase. J. Chem. Ecol. 22:801-805.

PolityCKA, B. 1996. Peroxidase activity and lipid peroxidation in roots of cucumber seedlings influenced by derivatives of cinnamic and benzoic acids. Acta Physiol. Plant. 18:365-370.

PolitycKA, B. 1998. Phenolics and the activities of phenylalanine ammonia-lyase, phenol- $\beta$-glucosyltransferase and $\beta$-glucosidase in cucumber roots as affected by phenolics allelochemicals. Acta Physiol. Plant. 20:405-410.

Romero-Romero, T., Sanchez-Nieto, S., San Juan-Badillo, A., Anaya, A. L., and Cruz-Ortega, R. 2005. Comparative effects of allelochemical and water stress in roots of Lycopersicon esculentum Mill. (Solanaceae). Plant Sci. 168:1059-1066.

SCAndalios, J. G. 1993. Oxygen stress and superoxide dismutase. Plant Physiol. 101:7-12.

Scandalios, J. G., GuAN, L., and Polidoros, A. N. 1997. Catalases in plants: gene structure, properties, regulation and expression, pp. 343-406, in J. G. Scandalios (ed.). Oxidative Stress and the Molecular Biology of Antioxidant Defences. Cold Spring Harbor Laboratory Press, New York.

ScebBa, F., Sebastiani, L., and Vitagliano, C. 1998. Changes in activity of antioxidative enzymes in wheat (Triticum aestivum) seedling under cold acclimation. Physiol. Plant. 104:747-752.

Shon, M. K. and Einhellig, F. A. 1982. Allelopathic effects of cultivated sunflower on grain sorghum. Bot. Gaz. 143:505-510.

Vranova, E., InZe, D., and VAn Breusegem, F. 2002. Signal transduction during oxidative stress. J. Exp. Bot. 53:1227-1236.

WeIR, T. L., PARK, S.-W., and VivanCO, J. M. 2004. Biochemical and physiological mechanisms mediated by allelochemicals. Curr. Opin. Plant Biol. 7:472-479.

WiLsON, R. E. and RICE, E. L. 1968. Allelopathy as expressed by Helianthus annuus and its role in old-field succession. Bull. Torrey Bot. Club 95:432-448. 
YU, J. Q., YE, S. F., ZHANG, M. F., and Hu, W. H. 2003. Effects of root exudates and aqueous root extracts of cucumber (Cucumis sativus) and allelochemicals, on photosynthesis and antioxidant enzymes in cucumber. Biochem. Syst. Ecol. 31:129-139.

Zeng, R. S., LuO, S. M., ShI, Y. H., ShI, M. B., and TU, C. Y. 2001. Physiological and biochemical mechanism of allelopathy of secalonic acid F on higher plants. Agron. J. 93:72-79. 